\title{
Detection of genetically modified maize in processed products, dry grains, and corn ears intended for fresh consumption in South Brazil
}

\author{
C.A.M. Oliveira ${ }^{1}$, C.M. Kommers ${ }^{1}$, F.K.M. Lehmann ${ }^{1}$, A.S.K. Fonseca ${ }^{2}$, \\ N. Ikuta ${ }^{1,2}$ and V.R. Lunge ${ }^{1,2}$ \\ ${ }^{1}$ Laboratório de Diagnóstico Molecular, Universidade Luterana do Brasil, \\ Canoas, RS, Brasil \\ ${ }^{2}$ Simbios Biotecnologia, Canoas, RS, Brasil \\ Corresponding author: V.R. Lunge \\ E-mail: lunge@ulbra.br
}

Genet. Mol. Res. 15 (4): gmr15048818

Received May 17, 2016

Accepted September 5, 2016

Published October 17, 2016

DOI http://dx.doi.org/10.4238/gmr15048818

Copyright (C) 2016 The Authors. This is an open-access article distributed under the terms of the Creative Commons Attribution ShareAlike (CC BY-SA) 4.0 License.

\begin{abstract}
Conventional and genetically modified (GM) maize cultivars have been widely planted in Brazil to produce grains for processed food, feed, or to be consumed fresh as corn ears. This study used real-time PCR to detect GM maize in processed products and fresh commercial corn ears produced in the last two years in South Brazil. Eighteen conventional and GM maize cultivars were obtained from seed production companies and 50 commercial samples (including canned corn, corn flour, dry grains, and fresh corn ears) were purchased in small local stores and supermarkets. All samples were analyzed by real time TaqMan PCR to detect one constitutive maize gene $(h m g)$ and three genetic regions present in GM plants (p-35S promoter, major gene cry 1A.105, and t-Nos terminator). Each commercial sample was classified as conventional or GM based on the PCR results. PCR targeting the
\end{abstract}


$h m g$ gene generated positive results from all DNA samples, which were further tested with the GM targets. These targets were not detected in the five conventional maize cultivars, but were detected in the GM seeds hosting these fragments. Analysis of processed foods identified four cultivars as conventional and six as GM, which were mostly correctly labeled. Seven (53.8\%) dry grain samples were classified as conventional, while six (46.2\%) were classified as GM. Three (11.1\%) corn ear samples were identified as conventional, and the remaining 24 $(88.9 \%)$ were GM maize. These results demonstrate the high frequency of GM maize in processed products, including fresh corn ears intended for consumption in South Brazil.

Key words: GM crops; Real-time PCR; Transgenic maize

\section{INTRODUCTION}

Maize (Zea mays), or corn, is one of the most widely consumed grains by humans and livestock throughout the world. As a component of the human diet, it can be consumed fresh as corn ears, used as a staple food for processed meals (polenta, tortillas, burritos), or as a snack food, such as popcorn and corn chips. In general, variation in the moisture content accounts for the different properties of these foods; while corn ears have more than $70 \%$ water content, dry grains (used in processed foods) have only 15 to $20 \%$ (Silva et al., 2010).

Due to its importance in human and animal diets, maize is a leading crop plant in Brazil, with a plantation area of 15.8 million hectares and a total production of 85.5 million tons in the 2014/2015 crop. It is the second most cultivated grain, accounting for $40 \%$ of the total crop production in the country $(\mathrm{CONAB}, 2015)$. Data from maize producing companies reveal that 478 cultivars were available to farmers during the last crop in Brazil, including 292 genetically modified (GM or transgenic) and 186 conventional cultivars (Cruz, 2014; Cruz, 2015). In addition, there were 320 different genetic materials, 186 of which were marketed as GM and conventional, and 134 commercialized only as GM crops (lacking the conventional option). All of these cultivars can be used to produce dry grains, silage for livestock animals, and corn ears. In the last crop, only 17 cultivars were recommended for the production of corn ears, while 474 cultivars were indicated for dry grain production and whole plant silage. Four other cultivars were recommended for the production of popcorn and corn starch (Cruz, 2015).

GM corn crops express insecticidal genes (cry or vip), derived from the soil bacterium Bacillus thuringiensis (Bt), in order to control the major Lepidoptera species. Currently commercialized GM biotech crops have different events to achieve this effective control, such as Herculex I (TC1507), YieldGard (MON810), Agrisure TL (Bt11), TL Viptera (MIR162), and VT PRO (MON890314). Plant leaves produce different Cry proteins according to the inserted event, such as Cry 1F, Cry 1Ab, Cry 1A.105, Cry 2Ab2, Cry 3Bb1, Cry 34Ab1, and Cry 35Ab2. More recently, GM seeds with insecticidal traits stacked with tolerance to the herbicides glyphosate (Roundup Ready NK603 and TG GA21) or glufosinate-ammonium (Liberty Link Technology) have also been commercialized in Brazilian producing regions (Cruz, 2015). All of these GM events carry at least one promoter and one terminator region, in addition to the main gene (cry, vip, epsps, etc.). The promoter region $\mathrm{p}-35 \mathrm{~S}$ (from the cauliflower mosaic virus) and the terminator t-Nos (from the nopaline synthase gene) are the

Genetics and Molecular Research 15 (4): gmr15048818 
most commonly used in GM maize seeds (Wolf et al., 2000; Dinon et al., 2011).

The use of GM crops has many social, environmental, and economic advantages. GM crops reduce the use of chemical insecticides; provide benefits to human health, the environment, and biodiversity; and lead to higher productivity increases income for farmers (Romeis et al., 2006; Hutchison et al., 2010; Tabashnik, 2010; Ronald, 2011). These advantages explain the intensive use of biotech crops since their first commercial release in 1996. The total cumulative area of transgenic crops exceeds 1.8 billion hectares with a 3 to $4 \%$ consistent increase per year. As a consequence, GM maize products have been increasingly marketed in the last few years (James, 2014).

The production of food and feed from GM plants is subject to specific regulation. Products for human or animal use containing more than 1\% GM organisms have to be labeled to inform consumers (Brazilian Government - Law No. 4680, April 25, 2003; Marinho et al., 2014). The aim of the present study was to detect GM maize in industrially processed products, dry grains, and corn ears commercialized for fresh consumption in the Rio Grande do Sul State, south of Brazil. All samples were tested for the presence of two genetic regions usually present in GM crops (the p-35S promoter and the t-NOS terminator) and one main gene (cry 1A.105) present in the most commercialized GM corn crops grown in this region (VT PRO).

\section{MATERIAL AND METHODS}

\section{Samples}

Seeds of 18 maize cultivars were kindly provided by cooperatives, seed companies, and agricultural markets (Table 1). The cultivars were obtained from the commercial companies Agroceres, Biomatrix, Dow Agroscience, Dekalb, Santa Helena Seeds, and Syngenta (Celeron, Formula, and Status brands). These cultivars were approved to be planted in the last Brazilian crop by the National Biosafety Technical Commission. In addition, 50 commercial samples were purchased from small local stores and supermarkets. The products included canned corn $(\mathrm{N}=4)$, corn flour $(\mathrm{N}=6)$, dry grains currently used in feed $(\mathrm{N}=13)$, and fresh corn ears $(\mathrm{N}=$ 27). All these samples were produced between 2014 and 2015. The corn ears were marketed in 27 different commercial plastic bags, each containing three or four corn ears, and were produced by 17 different companies located in 12 cities from Rio Grande do Sul State, Brazil (Figure 1).

\section{DNA extraction}

All samples were processed prior to DNA extraction. Grains were first macerated and 0.1 to $0.2 \mathrm{mg}$ was used for the analysis of DNA. DNA was extracted by an adapted silica method (Boom et al., 1990) using commercial reagents (Simbios Biotecnologia, Cachoeirinha, RS, Brazil). Briefly, $1350 \mu \mathrm{L}$ lysis solution (5 M guanidine tiocianate, $0.1 \mathrm{M}$ Tris-HCl, $\mathrm{pH} 6.4$ ) was added to each sample, which were then incubated at $60^{\circ} \mathrm{C}$ for $10 \mathrm{~min}$. After centrifugation $(10,000 \mathrm{~g}, 3 \mathrm{~min})$, the supernatant was transferred to a tube containing $20 \mu \mathrm{L}$ silica suspension. This mixture was stirred and centrifuged $(10,000 \mathrm{~g}, 3 \mathrm{~min})$, and the pellet was washed twice with $1000 \mu \mathrm{L}$ wash solution $\mathrm{A}$ ( $5 \mathrm{M}$ guanidine tiocianate, $0.1 \mathrm{M}$ Tris- $\mathrm{HCl}, \mathrm{pH}$ 6.4), twice with wash solution B ( $75 \%$ ethanol), and once with wash solution C (100\% ethanol). The silica was dried and the DNA was separated using $50 \mu \mathrm{L}$ eluting solution $(10 \mathrm{mM}$ Tris-HCl, $\mathrm{pH}$ 8.0, 1 mM EDTA).

Genetics and Molecular Research 15 (4): gmr15048818 


\section{Table 1. Maize seed cultivars used in the present study.}

\begin{tabular}{|c|c|c|c|c|c|}
\hline Type & Cultivars & $h m g$ & $\mathrm{p}-35 \mathrm{~S}$ & cry $1 \mathrm{~A} .105$ & t-Nos \\
\hline \multirow[t]{13}{*}{ Transgenic } & BM 915 PRO & + & + & + & + \\
\hline & \begin{tabular}{|l|} 
SHS 7920 PRO \\
\end{tabular} & + & + & + & + \\
\hline & BM 3063 PRO2 & + & + & + & + \\
\hline & BM 3066 PRO2 & + & + & + & + \\
\hline & SHS 7915 PRO & + & + & + & + \\
\hline & SHS 7990 PRO2 & + & + & + & + \\
\hline & DKB 240 PRO & + & + & + & + \\
\hline & 2B647 PW & + & + & + & + \\
\hline & AG 5011 & + & + & - & - \\
\hline & CELERON TL & + & + & - & + \\
\hline & FORMULA TL & + & + & - & + \\
\hline & STATUS VIP & + & - & - & + \\
\hline & STATUS VIP3 & + & + & - & + \\
\hline \multirow[t]{5}{*}{ Conventional } & AG 8025 & + & - & - & - \\
\hline & BM 911 & + & - & - & - \\
\hline & FORMULA & + & - & - & - \\
\hline & CELERON & + & - & - & - \\
\hline & \begin{tabular}{|l|} 
STATUS \\
\end{tabular} & + & - & - & - \\
\hline
\end{tabular}

hmg - endogenous corn gene; p-35S - promoter region; cry 1A.105 - main maize gene for the MON89034 event; t-Nos - terminator region. Biomatrix (BM), Santa Helena Seeds (SHS), Dekalb (DKB), Dow Agroscience (2B), Agroceres (AG), and Syngenta (Celeron, Formula, and Status brands).

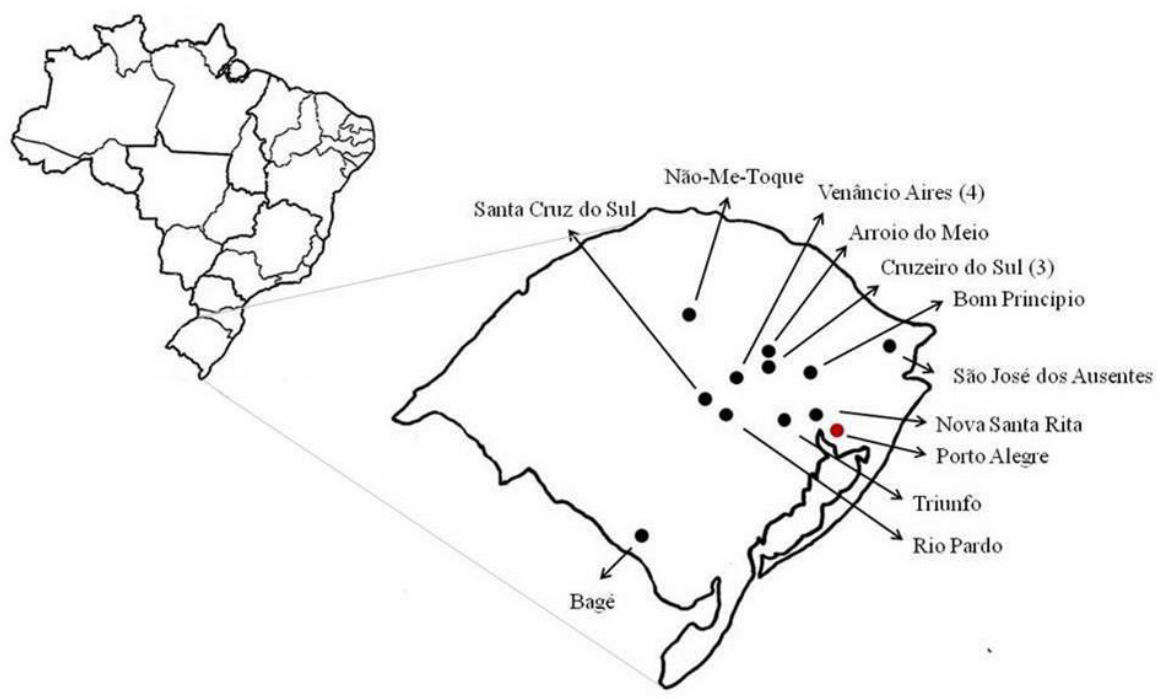

Figure 1. Cities of the corn ears producers in Rio Grande do Sul. The state capital, Porto Alegre, is highlighted in red.

\section{Primers and probes}

Primers and probes targeting high mobility group ( $h m g$, a constitutive maize gene), p-35S, the cry 1A.105 gene, and t-Nos were selected based on the results of previous studies (Table 2). All primers and probes were evaluated using the Primer Express software (Applied Biosystems, Norwalk, CT, USA). Oligonucleotides were purchased from Applied Biosystems or Integrated DNA Technologies (Coralville, IA, USA). 
Table 2. Primers and TaqMan probes used in the real time PCR.

\begin{tabular}{|c|c|c|c|}
\hline Primers & Sequence (orientation 5'-3') & Amplicon size (bp) & Reference \\
\hline $\mathrm{p}-35 \mathrm{~S}-\mathrm{F}$ & GCC TCT GCC GAC AGT GGT & \multirow[t]{3}{*}{82} & \multirow{3}{*}{$\begin{array}{l}\text { Waiblinger et al., } 2008 \\
\text { Huber et al., } 2013\end{array}$} \\
\hline $\mathrm{p}-35 \mathrm{~S}-\mathrm{R}$ & AAG ACG TGG TTG GAA CGT CTT C & & \\
\hline $\mathrm{p}-35 \mathrm{~S}-\mathrm{P}$ & FAM-CAA AGA TGG ACC CCC ACC CAC G- ZEN-IOWA BLACK FQ & & \\
\hline t-Nos - F & CAT GTA ATG CAT GAC GTT ATT TAT G & \multirow[t]{3}{*}{84} & \multirow{3}{*}{$\begin{array}{l}\text { Reiting et al., } 2007 \\
\text { Huber et al., } 2013\end{array}$} \\
\hline t-Nos - R & TTG TTT TCT ATC GCG TAT TAA ATG T & & \\
\hline t-Nos - P & VIC-ATG GGT TTT TAT GAT TAG AGT CCC GCA A- ZEN-IOWA BLACK FQ & & \\
\hline cry1A.105 - F & TCAGAGGTCCAGGGTTTACAGG & \multirow[t]{3}{*}{113} & \multirow[t]{3}{*}{ Dinon et al., 2011} \\
\hline cry1A105 - R & GTAGTAGAGGCATAGCGGGATTCTTG & & \\
\hline cry1A105 - P & FAM-AGACATTCTTCGTCGCACAAGTGGAGGACC-ZEN -IOWA BLACK FQ & & \\
\hline ZM1- F(hmg) & TTGGACTAGAAATCTCGTGCTGA & \multirow[t]{3}{*}{79} & \multirow[t]{3}{*}{ Corbisier et al., 2010} \\
\hline ZM1- R (hmg) & GCTACATAGGGAGCCTTGTCCT & & \\
\hline ZM1- P(hmg) & VIC-CAATCCACACAAACGCACGCGTA- IOWA BLACK FQ & & \\
\hline
\end{tabular}

F: Forward primer; R: reverse primer; FAM and VIC TaqMan reporter dye labels; MGB and ZEN-IOWA BLACK FQTaqMan quencher dye labels.

\section{Real time-PCR}

Real-time TaqMan PCR assays were performed using StepOne Plus ${ }^{\circledR}$ (Applied Biosystems). First, PCR with the hmg primers/probe set was carried out to evaluate the quality of all extracted DNA. Next, three separate PCRs were run to detect p-35S, t-Nos, and cry 1A-105. All reactions were carried out in a total volume of $30 \mu \mathrm{L}$ with $2 \mu \mathrm{L}$ DNA template, $1.5 \mathrm{U}$ Taq DNA polymerase and the respective enzyme reaction buffer (Ludwig Biotecnologia, Porto Alegre, RS, Brazil), $1.5 \mathrm{mM} \mathrm{MgCl}, 0.06 \mathrm{mM}$ each dNTP, $0.25 \mu \mathrm{M}$ each primer, and $0.125 \mu \mathrm{M}$ probe(s). The following cycling parameters were used: one cycle of $95^{\circ} \mathrm{C}$ for $3 \mathrm{~min}$, 40 cycles of $95^{\circ} \mathrm{C}$ for $15 \mathrm{~s}$, and $60^{\circ} \mathrm{C}$ for $60 \mathrm{~s}$. Cycle threshold was defined for each sample and compared to that of the positive and negative controls.

\section{RESULTS}

\section{TaqMan PCR conditions}

All probes and primers used in this study were first tested using two GM crop cultivars hosting the VT PRO event (BM 915 PRO and SHS 7920 PRO). Both generated positive results for the four targets: the constitutive maize gene $h m g$, the promoter region $\mathrm{p}-35 \mathrm{~S}$, the main $\mathrm{Bt}$ gene cry 1A.105, and the terminator region t-Nos. The TaqMan PCR assays proved to be effective at detecting all four different targets for these two cultivars (Table 1).

\section{Detection of GM maize events in commercial cultivars}

The remaining 16 maize seeds, including five conventional and $11 \mathrm{GM}$ crops, were analyzed using the four PCR assays described (Table 1). Briefly, all samples were found to be positive for the endogenous maize gene hmg. Conventional maize seeds (AG 8025, BM 911, Celeron, Formula, and Status) presented negative results for the other three targets. Of the $11 \mathrm{GM}$ crops, 10 amplified for the p-35S promoter and the t-Nos terminator gene fragments, while six were also positive for the $c r y 1 \mathrm{~A} .105$ gene. These remaining six maize cultivars were all positive for cry $1 \mathrm{~A} .105$, p-35S, and t-Nos. As defined by the producers, all of those cultivars host the GM event PRO (MON89034). The cultivars AG 5011 and Status VIP presented 
positive results only for $\mathrm{p}-35 \mathrm{~S}$ and $\mathrm{t}-\mathrm{Nos}$, respectively. The remaining three samples (Celeron TL, Formula TL, and Status VIP3) presented positive results for both the p-35S and t-Nos regions (Table 1).

\section{Detection of GM maize events in processed foods and dry grains}

All 23 industrially processed products (six corn flours, four canned corns, and 13 dry grains for animal feed) tested positive for the $h m g$ gene (Table 3). In 11 samples, none of the maize GM targets was detected, and they were classified as conventional (non-GM). Of the other 12 samples, at least one of the GM targets was detected, and they were defined as GM foods. Seven samples were positive for the three GM targets, two for the p-35S and t-Nos regions, two for $\mathrm{p}-35 \mathrm{~S}$, and one for $\mathrm{t}-\mathrm{Nos}$ (Table 3 ). Among the 12 transgenic samples, only the five corn flours had a GM label on their packaging.

Table 3. Description of the commercial samples: industrially processed foods (corn flours and canned corn), dry grains, and corn ears.

\begin{tabular}{|c|c|c|c|c|c|c|}
\hline & $\mathrm{N}$ & $h m g$ & $\mathrm{p}-35 \mathrm{~S}$ & cry 1 A. 105 & t-Nos & Classification \\
\hline \multirow[t]{2}{*}{ Corn flours } & 1 & + & - & - & - & Conventional \\
\hline & 5 & + & + & + & + & GM \\
\hline \multirow[t]{5}{*}{ Dry grains } & 2 & + & + & - & + & GM \\
\hline & 2 & + & + & + & + & GM \\
\hline & 1 & + & + & - & - & GM \\
\hline & 7 & + & - & - & - & Conventional \\
\hline & 1 & + & - & - & + & GM \\
\hline \multirow[t]{2}{*}{ Canned corn } & 3 & + & - & - & - & Conventional \\
\hline & 1 & + & + & - & - & GM \\
\hline \multirow[t]{5}{*}{ Corn ears } & 19 & + & + & + & + & GM \\
\hline & 3 & + & - & - & - & Conventional \\
\hline & 1 & + & + & - & - & GM \\
\hline & 1 & + & - & - & + & GM \\
\hline & 3 & + & + & - & + & GM \\
\hline
\end{tabular}

hmg - endogenous corn gene; p-35s - promoter region; cry 1A.105 - main maize gene for the MON89034 event; t-Nos - terminator region.

\section{Detection of GM maize events in corn ears}

Real-time PCR assays were used to detect the presence of transgenic maize in 27 commercial samples of corn ears. Grains of all samples tested positive for the endogenous $h m g$ gene. Analysis of the three specific GM targets revealed that only three samples were negative, and these were classified as conventional. The remaining $24(88.9 \%)$ corn ear samples were positive for at least one DNA region of the GM crops (Table 3). Interestingly, 19 samples were positive for the three targets, meaning that they all carry the transgenic event VT PRO (MON89034).

\section{DISCUSSION}

GM maize food and feed have been marketed worldwide. In Brazil, all food products intended for human and animal consumption containing over 1\% GM crops is required to be properly labeled (Brasil, 2003). Consequently, immunological and molecular biology 
techniques have been developed to detect the presence of specific GM DNA fragments in food and feed products. Immunological assays (such as enzyme linked immunosorbent assay and immunochromatography) are fast and user-friendly and require relatively low investment in terms of equipment and personnel. The immunochromatographic strip test is the mostdisseminated assay used in the field, and is even used by farmers to separate GM from nonGM crops. However, this assay detects specific transgenic proteins (Bt crystal protein in maize or EPSPS in soybean), which are often not readily available in some plants, seeds, and consequently, food products (Nascimento et al., 2012; Cantelmo et al., 2013).

Molecular biology assays (mainly PCR) are specific, sensitive, and have been widely used to detect the presence of GM crops. Although requiring special reagents and equipment, PCR can detect the presence of specific exogenous genes inserted into the plant genome (including the seeds), and represents the most widely used method to detect GM food and feed (Dinon et al., 2011; Branquinho et al., 2013; Cantelmo et al., 2013). In the present study, we used real time PCR to detect three GM-specific fragments: the promoter region p-35S derived from the cauliflower mosaic virus (Waiblinger et al., 2008; Huber et al., 2013), the terminator region, t-Nos, derived from the nopaline synthase gene of Agrobacterium tumefaciens (Reiting et al., 2007; Huber et al., 2013), and the main cry1A.105 gene from Bt (Dinon et al., 2011). These PCR assays were successfully implemented, in addition to an assay targeting the constitutive hmg gene, which was used as an endogenous control (Corbisier et al., 2010). Two GM crop cultivars carrying the VT PRO event (BM 915 PRO and SHS 7920 PRO) presented positive results for all three targets. Furthermore, the other conventional and GM maize cultivars presented results that were expected based on register information, as demonstrated in previous studies (Reiting et al., 2007; Waiblinger et al., 2008; Dinon et al., 2011; Huber et al., 2013).

All of the food samples analyzed were positive for the endogenous $h m g$ gene, demonstrating the absence of inhibition in the PCR and the presence of sufficient genetic material in these highly processed foods. Previous studies have demonstrated that it is not possible to detect oils and refined starches derived from GM crops because of the excessive heat, low pH, and enzymes used in the processing of corn flour products (Conceição et al., 2006), The five flour samples that had a GM label were positive for all of the tested targets, showing the presence of grains with the VT PRO event. The only non-labeled flour was negative for the three GM targets. A study was previously performed to verify compliance with Brazilian laws on the reporting of GM crops in food (Branquinho et al., 2013). Those authors reported the occurrence of several food products with GM organisms that were not properly labeled between 2011 and 2012. In the following year, the same products were properly labeled in accordance with Brazilian law. Another study conducted in Turkey revealed the presence of GM maize events in the feed composition used for livestock production (Meriç et al., 2014).

Conversely, the majority of corn ears ( 24 of $27,88.9 \%$ ), collected in the market and produced by small companies in different regions of Rio Grande do Sul State, were positive for at least one GM target (p-35S, t-Nos, and/or the cry 1A.105 gene). Those results demonstrate the intensive use of GM cultivars to produce commercial corn ears for human consumption. Furthermore, 19 samples were positive for the four targets, demonstrating that they are probably cultivars containing the GM VT PRO (MON89034) event. This may be due to the majority of the GM maize cultivars commercialized in the current season $(55 \%)$ carrying the VT PRO event (Cruz, 2014; Cruz, 2015).

Crops used for corn ear production have been developed to meet characteristics sought

Genetics and Molecular Research 15 (4): gmr15048818 
by consumers, which include intense yellow grains, fruity and sugary taste, soft texture, and being free of spike damage. Some of these are still planted to produce corn ears and/or sweet corn (Lopes et al., 2014). In the last crop season (2014/15), 17 maize cultivars were suitable for the production of corn ears, and only one of those hosts the MON89034 event (VT PRO). This specific cultivar has not been widely distributed and commercialized to the small farmers that plant and sell corn ears to the commercial companies (Cruz, 2014). It is likely that several of the 292 GM cultivars used for other purposes (dry grain, silage) have been widely planted in the field. Maize in Brazil is produced widely by small farmers, who do not usually have the opportunity to select cultivars and purchase the seeds from local markets with restricted commercial options. Therefore, seeds are used for the production of dry grains and silage because they are commonly available in the market (Cruz, 2015).

Non-transgenic corn crops can be pollinated by transgenic plants grown in neighboring locations (Devos et al., 2009). Good management practice of transgenic crops (use of natural barriers, cultivation of conventional plants in the borders, postponing or advancing sowing to the flowering period) could help to avoid the contamination of non-transgenic crops (Palaudelmàs et al., 2012). Of note, producers have responsibility, especially in organic production, for the accuracy of the information provided about the crop (CIB, 2011). According to Brazilian law, the use of transgenic grains is also forbidden in organic products; therefore, producers should avoid any possible contamination with GM maize (MAPA, 2015; Santos, 2015). Currently, $46 \%$ of maize produced comes from family farms in Brazil, many of which are focused on organic corn production (MDA, 2015).

The present study has two limitations. First, not all of the 21 transgenic maize events released for sale in Brazil were tested (although the GM events tested here represent more than $95 \%$ of the GM seeds produced in the last crop). Second, the number of analyzed samples used to represent the southern region of Brazil or the whole country is low.

In conclusion, GM maize was detected in industrially processed commercial products and fresh corn ears in Rio Grande do Sul State, south of Brazil. There was a high frequency of GM maize in processed products, dry grains, and corn ears intended for fresh consumption in South Brazil. Most food was found to carry the cry 1A.105 gene, demonstrating the intensive use of GM maize cultivars with the VT PRO (MON89034) event.

\section{Conflicts of interest}

The authors declare no conflict of interest.

\section{ACKNOWLEDGMENTS}

The authors thank the students of Laboratório de Diagnóstico Molecular of ULBRA for their technical collaboration in this study. The authors also thank FAPERGS for the scientific initiation scholarship awarded to the author C.A.M. Oliveira and CNPq for research grants to C.M. Kommers, N. Ikuta, and V.R. Lunge.

\section{REFERENCES}

Boom R, Sol CJ, Salimans MM, Jansen CL, et al. (1990). Rapid and simple method for purification of nucleic acids. $J$. Clin. Microbiol. 28: 495-503.

Genetics and Molecular Research 15 (4): gmr15048818 
Branquinho MR, Gomes DMV, Ferreira RTB, Lawson-Ferreira, et al. (2013). Detection of genetically modified maize events in Brazilian maize-derived food products. Food Sci. Technol. (Campinas) 33: 399-403. http://dx.doi. org/10.1590/S0101-20612013005000063

Brasil (2003). Decreto n 4.680, 24 de Abril de 2003. Regulamenta o acesso a informação (Lei n. 8078, 11 de Setembro de 1990) concernente a alimentos e ingredientes geneticamente modificados. D.O.U. Diário Oficial da União, Brasília, DF. Available at [http://www.planalto.gov.br/ccivil_03/decreto/2003/d4680.htm]. Accessed February 25, 2016.

Cantelmo NF, Von Pinho EVR, Von Pinho RG, Von Pinho IV, et al. (2013). Detection of transgenic events in maize using immunochromatographic strip test and conventional PCR. Cienc. Agrotec. 37: 404-409. http://dx.doi.org/10.1590/ $\underline{\text { S1413-70542013000500003 }}$

CIB (2011). Conselho de Informação sobre Biotecnologia - Coexistência de Milho GM e não-GM em cultivos comerciais. Available at [cib.org.br/wp-content/uploads/2011/10/estudos_cientificos_ambiental_09.pdf]. Acessed June 04, 2016.

CONAB (2015). Companhia Nacional de Abastecimento - Levantamento de Safra 2014/15. Available at [http://www. conab.gov.br/OlalaCMS/uploads/arquivos/15_10_16_10_52_19_safras_outu_2015.pdf]. Accessed October 27, 2015.

Conceição FR, Moreira AN and Binsfeld PC (2006). Detecção e quantificação de organismos geneticamente modificados em alimentos e ingredientes alimentares. Cienc. Rural 36: 315-324. http://dx.doi.org/10.1590/S0103$\underline{84782006000100053}$

Corbisier P, Bhat S, Partis L, Xie VR, et al. (2010). Absolute quantification of genetically modified MON810 maize (Zea mays L.) by digital polymerase chain reaction. Anal. Bioanal. Chem. 396: 2143-2150. http://dx.doi.org/10.1007/ s00216-009-3200-3

Cruz JC (2014). Embrapa Milho e Sorgo. 478 Cultivares de milho estão disponíveis no mercado de sementes do Brasil para a safra 2014/15. Available at [http://www.cnpms.embrapa.br/milho/cultivares/]. Accessed December 15, 2015.

Cruz JC (2015). Embrapa Milho e Sorgo. 477 Cultivares de milho estão disponíveis no mercado de sementes do Brasil para a safra 2015/16. Available at [http://www.cnpms.embrapa.br/milho/cultivares/]. Accessed December 17, 2015.

Devos Y, Demont M, Dillen K, Reheul D, et al. (2009). Coexistence of genetically modified (GM) and non-GM crops in the European Union. A review. Agron. Sustain. 29: 11-30. http://dx.doi.org/10.1051/agro:2008051

Dinon AZ, Prins TW, van Dijk JP, Arisi ACM, et al. (2011). Development and validation of real-time PCR screening methods for detection of cry1A.105 and cry2Ab2 genes in genetically modified organisms. Anal. Bioanal. Chem. 400: 1433-1442. http://dx.doi.org/10.1007/s00216-011-4875-9

Huber I, Block A, Sebah D, Debode F, et al. (2013). Development and validation of duplex, triplex, and pentaplex realtime PCR screening assays for the detection of genetically modified organisms in food and feed. J. Agric. Food Chem. 61: 10293-10301. http://dx.doi.org/10.1021/jf402448y

Hutchison WD, Burkness EC, Mitchell PD, Moon RD, et al. (2010). Areawide suppression of European corn borer with Bt maize reaps savings to non-Bt maize growers. Science 330: 222-225. http://dx.doi.org/10.1126/science.1190242

James C (2014). Global review of commercialized transgenic crops: 2014. The International Service for the Acquisition of Agri-biotech Applications (ISAAA). Available at [http://www.isaaa.org/gmapprovaldatabase/approvedeventsin/ default.asp?CountryID=BR\&Country=Brazil]. Accessed November 25, 2015.

Lopes AD, Scapim CA, Mangolin CA and Machado MF (2014). Genetic divergence among sweet corn lines estimated by microsatellite markers. Genet. Mol. Res. 13: 10415-10426. http://dx.doi.org/10.4238/2014.December.12.3

MAPA (2015). Ministério da Agricultura, Pecuária e Abastecimento - Legislação de Orgânicos. Available at [http://www. agricultura.gov.br/arq_editor/file/Desenvolvimento_Sustentavel/Organicos/Legislacao/Nacional/Lei_n_010_831_ de_23-12-2003.pdf]. Accessed March 23, 2016.

Marinho CD, Martins FJ, Amaral Júnior AT, Gonçalves LS, et al. (2014). Genetically modified crops: Brazilian law and overview. Genet. Mol. Res. 13: 5221-5240. http://dx.doi.org/10.4238/2014.July.7.15

MDA (2015). Ministério Desenvolvimento Agrário - Agricultura familiar produz $70 \%$ dos alimentos consumidos pelos brasileiros. Available at [http://www.mda.gov.br/]. Accessed November 12, 2015.

Meriç S, Çakir O, Turgut-Kara N and Arı S (2014). Detection of genetically modified maize and soybean in feed samples. Genet. Mol. Res. 13: 1160-1168. http://dx.doi.org/10.4238/2014.February.25.2

Nascimento VE, Von Pinho ÉV, Von Pinho RG and do Nascimento AD, Jr. (2012). Detection limits of the strip test and PCR for genetically modified corn in Brazil. Genet. Mol. Res. 11: 2497-2505. http://dx.doi.org/10.4238/2012.June.27.2

Palaudelmàs M, Melé E, Monfort A, Serra J, et al. (2012). Assessment of the influence of field size on maize gene flow using SSR analysis. Transgenic Res. 21: 471-483. http://dx.doi.org/10.1007/s11248-011-9549-z

Reiting R, Broll H, Waiblinger HU and Grohmann L (2007). Collaborative study of a T-nos real-time PCR method for screening of genetically modified organisms in food products. J. Verbr. Lebensm 2: 116-121. http://dx.doi. org/10.1007/s00003-007-0189-4

Genetics and Molecular Research 15 (4): gmr15048818 
Romeis J, Meissle M and Bigler F (2006). Transgenic crops expressing Bacillus thuringiensis toxins and biological control. Nat. Biotechnol. 24: 63-71. http://dx.doi.org/10.1038/nbt1180

Ronald P (2011). Plant genetics, sustainable agriculture and global food security. Genetics 188: 11-20. http://dx.doi. org/10.1534/genetics.111.128553

Santos N (2015). Cultura do Milho. Sistema de Produção de Milho Orgânico: 2013. Available at [http://www.zeamays. com.br/sistema-de-producao-de-milho-organico/]. Accessed November 6, 2015.

Silva PSL, Silva KMB, Silva PIB, Oliveira VR, et al. (2010). Rendimento de Espigas Verdes e Grãos de Cultivares de Milho em Competição com Plantas Daninhas. Planta Daninha 28: 77-85. http://dx.doi.org/10.1590/S0100$\underline{83582010000100010}$

Tabashnik BE (2010). Plant science. Communal benefits of transgenic corn. Science 330: 189-190. http://dx.doi. org/10.1126/science. 1196864

Waiblinger HU, Ernest B, Anderson A and Pietsch K (2008). Validation and collaborative study of a P-35S and T-nos duplex real-time PCR screening method to detect genetically modified organisms in food products. Eur. Food Res. Technol. 226: 1221-1228. http://dx.doi.org/10.1007/s00217-007-0748-z

Wolf C, Scherzinger M, Wurz A, Pauli U, et al. (2000). Detection of cauliflower mosaic virus by the polymerase chain reaction: testing of food components for false-positive 35Spromoterscreening results. Eur. Food Res. Technol. 210: 367-372. http://dx.doi.org/10.1007/s002170050565

Genetics and Molecular Research 15 (4): gmr15048818 